\begin{tabular}{|c|c|c|}
\hline \hline & International Journal of Current Research in \\
\hline & Biosciences and Plant Biology \\
\hline PXCELLENT \\
PUBLISHERS
\end{tabular}

\title{
Memecylon royenii Blume (Olisbeoideae: Melastomataceae): A new record for Tamil Nadu, India
}

\author{
R. Kottaimuthu ${ }^{\text {* }}$, S. Selvakumar², S. Eswaran², 3, P. Boomibalagan², 4 \\ and N. Karmegam5
}

\begin{abstract}
${ }^{1}$ Department of Botany, Alagappa University, Karaikudi-63o oo3, Tamil Nadu, India 2Department of Botany, Saraswathi Narayanan College, Madurai- 625 022, Tamil Nadu, India 3Presently at: Pasumpon Thiru Muthuramalinga Thevar Memorial College, Kamuthi-623 604, Tamil Nadu, India 4Presently at: Department of Botany, Rajadorai Singam Government Arts College, Sivaganga-630 561, Tamil Nadu, India 5Department of Botany, Government Arts College (Autonomous), Salem-636 007, Tamil Nadu, India
\end{abstract}

${ }^{*}$ Corresponding author; e-mail: kottaimuthu@yahoo.co.in

\begin{tabular}{ll}
\hline Article Info & ABSTRACT \\
\hline $\begin{array}{l}\text { Date of Acceptance: } \\
\text { 16 June } 2019\end{array}$ & $\begin{array}{l}\text { Memecylon royenii Blume is collected for the first time for Tamil Nadu from Sirumalai } \\
\text { Hills and reported as a new record for Melastomataceae of Tamil Nadu. A detailed } \\
\text { description, phenology, distribution and ecology along with a photo are provided for its } \\
\text { easy identification. }\end{array}$ \\
$\begin{array}{ll}\text { Date of Publication: } \\
\text { 06 July 2019 }\end{array}$ & \\
\cline { 1 - 1 } Keywords & \\
\hline $\begin{array}{l}\text { Additional flora } \\
\text { Distribution } \\
\text { Eastern Ghats } \\
\text { Sirumalai hills }\end{array}$ & \\
\hline
\end{tabular}

\section{Introduction}

Memecylon L. (Melastomataceae) is a palaeotropical genus and comprises more than 343 species (POWO, 2019). Das et al. (2018) have recognized 53 species from the present political boundary of India, while Vivekanandan (1983) has reported 18 species from Tamil Nadu. However, during the last few decades many new species have been discovered and added to the Melastomataceae of Tamil Nadu (Das et al., 2018; Manickam et al., 2007; Murugan and Gopalan, 2006; Murugan and Manickam, 2001; Murugan and Murthy, 2010; Murugan and Manickam 2000,
2001; Prabhu and Murugan, 2017; Pragasan and Parthasarathy, 2009; Udhayavani and Ramachandran, 2013; Viswanathan, 1995, 2001; Viswanathan and Manikandan, 2001; Viswananthan and Rajendran, 1993).

Taxonomically Memecylon is one of the most tricky group and the delimitation of species is mainly by traditional characters such as shape and size of leaves, position and nature of inflorescence, length of pedicels, shape and nature of cohesion of the calyx, and the presence or absence of disc rays (Kumar et al., 2004; Kottaimuthu and Vasudevan, 2015; Stone et al., 2014). Further, foliar sclereids 
and the nature of the embryo are also used as aids in the identification of the taxa (Rao and Bhupal, 1974; Rao and Dakshni, 1963; Rao et al., 1980). While working on the flora of southern Eastern Ghats, the first author collected some interesting specimens of Memecylon from the semi-evergreen forests of Sirumalai Hills. After critical examination of the specimen with pertinent literature (Bremer, 1979, 1987) it is confirmed as Memecylon royenii. This Indo-Lankan species was so far reported only from the states of Andhra Pradesh (Murugan and Gopalan, 2006) and Kerala (Rajendraprasad et al., 2006). Hence the present collection constitutes a new report for Tamil Nadu and it is discussed hereunder in detail.

Memecylon royenii Blume, Mus. Bot. 1(23): 360. 1851; K. Bremer in Opera Bot. 50: 19. 1979 \& in Dassanayakae \& Fosberg, Rev. Handb. Fl. Ceylon 6: 221. 1987; Murugan \& Gopalan in Indian J. Forest. 29(1): 107. 2006; M. Rajendraprasad \& al. in Indian Forester 132: 229. 2006.

Small tree, up to $5 \mathrm{~m}$ high; branchlets terete. Leaves opposite, broadly lanceolate or oblonglanceolate, $6.5^{-11} \times 2-3.8 \mathrm{~cm}$, apex shortly, sometimes obtusely acuminate, base cuneate, midrib prominent, sunken above, raised below, secondary veins obscure, 6-8 pairs, coriaceous, glossy above, yellowish below when dry, petiolate; petioles channeled on the upper side, petioles up to $7 \mathrm{~mm}$ long. Inflorescences axillary or in lateral, laxly branched umbels; peduncles 2-3 per node, terete, ridged, up to $5 \mathrm{~cm}$ long. Flowers small, $c a .5$ $\mathrm{mm}$ across; bracts oblong or ovate-oblong, 1-2 $\mathrm{mm}$ long, persistent. Hypantho-calyx campanulate, 2$2.5 \mathrm{~mm}$ wide, 4-lobed; calyx-lobes triangular to sub-orbicular, apex rounded, margin thin, scarious, bluish. Petals 4, blue, orbicular, up to 3 $\mathrm{mm}$ long, rounded at apex, clawed at base. Disc red-colored with prominent radiating rays. Stamens 8; filaments blue, filiform, ca. $4 \mathrm{~mm}$ long; anther connectives 1-1.4 $\mathrm{mm}$ long, glandular. Ovary globose, $1 \mathrm{~mm}$ across, papillate; styles blue, filiform; stigma simple. Berries globose, 6-7 $\mathrm{mm}$ across, yellowish green when ripe.

\section{Flowering \& Fruiting: April-May.}

Distribution: INDIA (Andhra Pradesh, Kerala and Tamil Nadu [present report]) and SRI LANKA.
Specimens examined: Tamil Nadu: Dindigul District; Sirumalai, on way to Kannadiparai, ca. $1080 \mathrm{~m}$ asl, 13.04.2009, RKM 63513 (Saraswathi Narayanan College Herbarium); Sirumalai, Nerkuthu Solai, 1120 m, 13.05.10, RKM 63515 (Saraswathi Narayanan College Herbarium).

\section{Acknowledgement}

Authors are thankful to 'retd' Dr. G.V.S. Murthy, Scientist 'G', Botanical Survey of India, Southern Regional Centre for granting permission to consult the herbarium and library. The first author (RK) thankfully acknowledge the DST-PURSE [SR/PURSE Phase 2/38 (G)] and MHRD-RUSA 2.o [F.24/51/2014-U, Policy (TNMulti-Gen), Dept. of Edn. Govt. of India] for the financial supports and infrastructure facilities.

\section{Conflict of interest statement}

Authors declare that they have no conflict of interest.

\section{References}

Bremer, K., 1979. Taxonomy of Memecylon (Melastomataceae) in Ceylon. Opera Botanica 50, 1-32.

Bremer, K., 1987. Memecylon. In: A Revised Handbook to the Flora of Ceylon. (Ed.: Dassanayakae, M. D., Fosberg, F. R.), Vol. VI, Amerind Publishing, New Delhi.

Das, M. D., Giri, G. S., Maity, D., 2018. Taxonomic status of Memecylon petiolatum Trimen ex Alston (Melastomataceae) and its extension of distribution to India. Fedd. Repert. 129, 51-57.

Kottaimuthu, R., Vasudevan, N., Saravanan, A., 2015. On the occurrence of Memecylon capitellatum $\mathrm{L}$. (Memecylaceae) in India. Taprobanica 7(2), 114117.

Kumar, E. S. S., Thulasidass, G., Yeragi, S. S., Nair, G. M., 2004. Memecylon sylvaticum Thw. (Melastomataceae)-A new record for India. J. Econ. Taxon. Bot. 28, 513-515.

Manickam, V. S., Murugan, C., Jothi, G. J., Sundaresan, V., 2007. Memecylon courtallense A new species (Melastomataceae) from Courtallum hills of Tamil Nadu, India. Indian $\mathrm{J}$. Forest. 30, 77-80.

Murugan, C., Gopalan, R., 2006. Four additions to Indian Memecylon L. (Melastomataceae) 
from South India. Indian J. Forest. 29, 105108.

Murugan, C., Manickam, V. S., 2001. Two distributional records for India. J. Econ. Taxon. Bot. 25, 346-349.

Murugan, C., Manickam, V. S., 2001. New species of Memecylon and Sonerila (Melastomataceae) from Southern Western Ghats of India. J. Econ. Taxon. Bot. 25, 509-513.

Murugan, C., Murthy, G. V. S., 2010. Memecylon macrocarpum Thwaites - An addition to Memecylaceae of India from Courtallum hills, Tamil Nadu. J. Econ. Taxon. Bot. 34, 522-523.

Murugan, C., Manickam, V. S., Sundaresan, V., 2001. Memecylon tirunelvelicum - A new species of Melastomataceae from Peninsular India. Novon 11, 197-199.

Murugan, C., Sundaresan, V., Jothi, G. J., 2000. Memecylon manickamii - A new species of Melastomataceae from the Western Ghats of Tamil Nadu. Kew Bull. 55, 1001-1003.

POWO., 2019. Memecylon. http://powo.science. kew.org/taxon/urn:lsid:ipni.org:names:26452-1.

Prabhu, S., Murugan, C., 2017. A new species of Memecylon (Melastomataceae) from the Western Ghats, India. Indian J. Forest. 40(1), 6971.

Pragasan, L. A., Parthasarathy, N., 2009. Memecylon parvifolium Thwaites (Melastomataceae) from southern Eastern Ghats - A new record to tree flora of India. J. Econ. Taxon. Bot. 33, 426-427.

Rajendraprasad, M., Prathapan, S. L., Pandurangan, A. G., Shaju, T., 2006. Memecylon royenii Blume (Melastomataceae): A new record for India. Indian Forester 132, 229-232.

Rao, T. A., Bhupal, P., 1974. The utility of sclereid typology in solving problems of synonymy in a few taxa of the genus Memecylon L. Proc. Nat. Acad. Sci. (Biol. Sci.) 80, 291-300.

Rao, T. A., Dakshni, K. M. M., 1963. Systematics of Memecylon-A preliminary survey based on the sclereid morphology. Proc. Nat. Acad. Sci. (Biol. Sci.) 58, 28-35.

Rao, T. A., Bremer, K., Chakraborti, S., 1980. Foliar sclereids in Sri Lanka (Ceylonese) species of Memecylon (Melastomataceae). Bot. Notis. 133, 397-401.

Stone, R. D., 2014. The species-rich, paleotropical genus Memecylon (Melastomataceae): Molecular phylogenetics and revised infrageneric classification of the African species. Taxon 63(3), 539-561.

Udhayavani, C., Ramachandran, V. S., 2013. On the occurrence of Memecylon clarkeanum Cogn. (Melastomataceae) - A vulnerable species from Nilgiri, Tamil Nadu, India. J. Threatened Taxa 5, 4811-4813.

Viswanathan, M. B., 2001. Two new species in Memecylon (Melastomataceae) from India. Nordic J. Bot. 21, 253-258.

Viswanathan, M. B., Manikandan, U., 2001. A new species, Memecylon mundanthuraianum, of Melastomataceae from India. Nordic J. Bot. 21, 259-262.

Viswanathan, M. B., Rajendran, A., 1993. Memecylon rivulare Bremer (Melastomataceae) - An addition to the Indian flora. Bull. Bot. Surv. India 35, 124-126.

Viswanathan, M. B., 1995. A note on the distribution and conservation status of Memecylon capitellatum Linn. in South India. Bull. Bot. Surv. India 37, 127-128.

\section{How to cite this article:}

Kottaimuthu, R., Selvakumar, S., Eswaran, S., Boomibalagan, P., Karmegam, N., 2019. Memecylon royenii Blume (Olisbeoideae: Melastomataceae): A new record for Tamil Nadu, India. Int. J. Curr. Res. Biosci. Plant Biol. 6(7), 26-28. doi: https://doi.org/10.20546/ijcrbp.2019.607.004 